\title{
Pendampingan Masyarakat Candi dalam Budidaya Tanaman Sawi dengan Metode Hidroponik di Kabupaten Sidoarjo
}

\author{
Vera Rimbawani, Son Fitroni Hidayat \\ Universitas Bhayangkara Surabaya \\ rimbawani@ubhara.ac.id,sonfitroni2@gmail.com
}

\begin{abstract}
:
The Brassica Juncea L cultivation using the hydroponic method was chosen as one of the programs for the community. Cultivation of Brassica Juncea L plants by hydroponics to get to know plants that are better without using soil and fertilizer and to save more land in the village of Sidoarjo temple. Assistance is done is to make the planting media and then socialize how to cultivate it and the obstacles that may arise and the solution to the community. The results of this assistance are expected by the community to be able to continue and develop this program ffter being left by a team of community service, so that it can benefit the community, at least to utilize vacant land and meet the needs of vegetables for the household, and if abundant harvests can be sold and eventually bought improve the economy of the community.
\end{abstract}

Keyword: Devotion, Brassica Juncea L, Hydroponics

\section{Pendahuluan}

Pengabdian masyarakat ini merupakan salah satu model kegiatan kepada masyarakat yang dilakukan oleh tim pengabdian masyarakat Universitas Bhayangkara Surabaya. Pengabdian masyarakat ini perlu diarahkan dalam memecahkan masalah yang dihadapi masyarakat setempat. Oleh karena itu pemecahan masalah dalam masyarakat perlu diupayakan pendekatan sosialisasi tentang tanaman hidroponik agar masyarakat candi sidoarjo lebih bisa mengenal tanaman hidroponik dan bisa memanfaatkan lahan yang kosong. Masyarakat desa Candi Sidoarjo sebenarnya sudah pernah melakukan tanaman hidroponik yaitu menanam sawi, akan tetapi medianya kurang memadai dan kurangnya pengetahuan tentang cara penanaman hidroponik dimasyarakat sekitar yang membuat tanaman 
hidroponik sudah tidak berkembang lagi. Maka dari itu tim pengabdian masyarakat Universitas Bhayangkara Surabaya memilih desa Candi sebagai tempat tujuan pengabdian masyarakat dan memilih budidaya tanaman sawi dengan cara hidroponik sebagai temanya, agar warga desa Candi Sidoarjo dapat meneruskan kembali budidaya tanaman hidroponik. Selain itu tim pengabdian masyarakat Universitas Bhayangkara Surabaya juga akan memberikan ilmu cara menanam tanaman hidroponik tersebut dengan cara bersosialisasi kepada warga di sekitar desa Candi Sidoarjo

Budidaya tanaman sawi dengan cara hidroponik merupakan salah satu model upaya dalam memecahkan masalah tentang tanaman hidroponik yang sudah mulai tidak berkembang lagi. tim pengabdian masyarakat Universitas Bhayangkara Surabaya memilih tanaman sawi dengan tujuan agar kedepannya tanaman sawi ini bisa dikonsumsi untuk kebutuhan sehari-hari atau bisa dijual kepada konsumen agar menambah pendapatan masyarakat Desa Candi tersebut.

Sayur merupakan sumber makanan yang mengandung gizi lengkap dan sehat. Sayur berwarna hijau merupakan sumber kaya karoten (provitamin A). Semakin tua warna hijaunya, maka semakin banyak kandungan karotennya. Salah satu sayuran yang sering dikonsumsi oleh masyarakat adalah sawi hijau (Brassica Juncea L). Sawi hijau, dapat dikategorikan kedalam sayuran daun. Sawi memiliki nilai ekonomis tinggi setelah kubis dan brokoli. Selain itu, tanaman ini juga mengandung mineral, vitamin, protein dan kalori. Oleh karena itu tanaman ini menjadi komoditas sayuran yang cukup populer di Indonesia.(Aksa, P, \& Subandriyanto, 2016) Sawi hijau sebagai bahan makanan sayuran mengandung zatzat gizi yang cukup lengkap sehingga apabila dikonsumsi sangat baik untuk mempertahankan kesehatan tubuh. Sebagai sayuran, caisim atau dikenal dengan sawi hijau mengandung berbagai khasiat bagi kesehatan. Kandungan yang terdapat pada caisim adalah protein, lemak, karbohidrat, Ca, P, Fe, Vitamin A, Vitamin B, dan Vitamin C.(Harahap, 2018)

Hidroponik adalah budidaya menanam dengan memanfaatkan air tanpa 
menggunakan tanah dengan menekankan pada pemenuhan kebutuhan nutrisi bagi tanaman. Kebutuhan air pada hidroponik lebih sedikit daripada kebutuhan air pada budidaya dengan tanah. Hidroponik menggunakan air yang lebih efisien, jadi cocok diterapkan pada daerah yang memiliki pasokan air yang terbatas.

Hidroponik merupakan salah satu cara bercocok tanam yang memanfaatkan air sebagai media nutrisi yang akan langsung diserap oleh tanaman sebagai penunjang tumbuh tanaman. Hidroponik Bisa dilakukan di lahan terbatas perkotaan. Nurtris pada Hidroponik diperoleh dengan mencampurkan formula cair A dan B, biasa disebut dengan pupuk AB Mix. Dalam ketersediaanya pupuk ini sedikit bisa ditemukan di toko-toko pertanian, khusus di Bandar Lampung belum ada, karena kurangnya sosialisasi bercocok tanam jenis ini.(Rakhman, Lanya, Rosadi, \& Zen Kadir, n.d.)

Sejak abad ke-16, percobaan tentang ilmu nutrisi dengan mengembangkan metode pertanian hidroponik telah dimulai. Semenjak itu, metode pertanian dengan hightechnology ini menjadi lebih populer dan dikenal di seluruh dunia. Hidroponik berasal dari bahasa Latin hydros yang berarti air dan phonos yang berarti kerja. Arti harfiah dari hidroponik adalah kerja air. Bertanam secara hidroponik kemudian dikenal dengan bertanam tanpa medium tanah (soilless cultivation, soilless culture). Mulanya, orang bertanam dengan metode hidroponik menggunakan wadah yang berisi air yang telah dicampur dengan pupuk mikro maupun makro.(Masduki, 2018)

Sejak 2600 tahun yang lalu, hidroponik diyakini sudah dikenal dan dipraktekkan. Sejarah mencatat, pada masa pemerintahan raja Nebuchadnezzar di Babilonia, hidroponik sudah diaplikasikan pada taman gantung yang dikenal dengan "Hanging Garden of Babylon". Hidroponik juga dipraktekkan oleh masyarakat Mesir, China dan suku Astek di Meksiko dengan model yang disebut "Chinampas". Chinampas (sering disebut Floating Garden) adalah pulau-pulau buatan berbentuk persegi empat yang diapungkan diatas danau untuk bercocok tanam. 
170 | Pendampingan Masyarakat Candi dalam Budidaya Tanaman Sawi ...

Di Indonesia, budi daya tanaman dengan sistem hidroponik mulai dikenal sejak awal 1980-sn. Tokoh yang mempopulerkan bertanam secara hidroponik antara lain Bob Sadino, yang saat itu juga menjadi pakar sekaligus narasumber dunia agribisnis. Pada awal perkembangannya, hidroponik lebih dianggap sebagai hobi semata, yakni untuk mengisi waktu luang dengan bertanam aneka tanaman (baik sayuran maupun buah) tanpa menggunakan media tanah. Selain itu, oleh sebagian kalangan, tanaman hidroponik juga dimaksudkan sebagai salah satu unsur dekoratif penghias rumah karena dianggap unik dan menarik. Tentu saja hal ini jauh berbeda dengan realita saat ini, ketika hidroponik sudah dijalankan secara komersial, untuk tujuan ekonomis. Perkembangan metode bercocok hidroponik di tanah air cukup bagus. Dengan ketersediaan lahan yang semakin sempit, masyarakat mulai tertarik dengan hidroponik karena bertanam dengan sistem hidroponik bisa dilakukan di mana saja dengan memanfaatkan setiap jengkal lahan yang tersedia. Dengan hidroponik, bertanam sayuran, buah, ataupun bunga mulai di halaman rumah, di samping rumah, di atas kolam ikan (menggunakan sistem aquaponik), di tembok atau pagar rumah, dan sebagainya. Dengan hidroponik, masyarakat yang tinggal di rumah susun atau apartemen pun bisa bertanam bunga ataupun sayuran. Bercocok tanam secara hidroponik menjadi alternatif paling realistis bagi masyarakat yang tinggal di perkotaan. Semakin meningkatnya pengetahuan dan kesadaran masyarakat akan pentingnya kesehatan tubuh dan lingkungan ikut mendukung perkembangan hidroponik. Orang semakin tahu bahwa sistem hidroponik ramah lingkungan karena penggunaan air dan pupuk lebih hemat dan efisien karena larutan nutrisinya dapat dipakai ulang. Hidroponik tidak banyak membutuhkan pestisida. Apalagi kualitas produk hidroponik memang tinggi. Buah dan sayuran tampak lebih segar dan lebih besar. Bagi pelaku agribisnis, bertanam hidroponik juga sangat menjanjikan karena tanaman bertumbuh lebih cepat sehingga lebih cepat panen, perawatan relatif mudah, tenaga kerja yang diperlukan lebih sedikit, dan harga jual produk hidroponik jauh lebih tinggi daripada produk yang ditanam dengan cara konvensional. Jadi tidak mengherankan apabila saat ini 
bermunculan pelaku agribisnis yang menekuni budi daya hidroponik sebagai andalan mereka.

Hidroponik adalah lahan budidaya pertanian tanpa menggunakan media tanah, sehingga hidroponik merupakan aktivitas pertanian yang dijalankan dengan menggunakan air sebagai medium untuk menggantikan tanah. Sehingga sistem bercocok tanam secara hidroponik dapat memanfaatkan lahan yang sempit.Pertanian dengan menggunakan sistem hidroponik memang tidak memerlukan lahan yang luas dalam pelaksanaannya, tetapi dalam bisnis pertanian hidroponik hanya layak dipertimbangkan mengingat dapat dilakukan di pekarangan rumah,atap rumah maupun lahan lainnya.(Roidah, 2014)

\section{Metode}

Metode yang digunakan dalam program ini adalah Participatory Action Research (PAR). PAR bertujuan untuk mendorong aksi transformatif, melibatkan sebanyak mungkin masyarakat warga atau anggota komunitas sebagai pelaksana PAR-nya sendiri. Dalam hal ini antara mahasiswa yang melaksanakan kegiatan pengabdian masyarakat dan masyarakat setempat melebur dan bekerja bersama warga dalam melakukan PAR. Tempat pelaksanaan pengabdian masyarakat di Desa Candi Kabupaten Sidoarjo dan lamanya proses pendampingan adalah 2 (dua) bulan.

\section{Hasil dan Diskusi}

Dari pengamatan potensi Desa Candi Sidoarjo adalah kondisi lahan kosong yang tidak dipergunakan sangat disayangkan jika tidak dimanfaat dengan baik. Maka dari itu, tim pengabdian masyarakat yang melaksanakan pengabdian ini melakukan sosialisasi budidaya menanam sawi menggunakan metode hidroponik. Untuk mengatasi kekosongan lahan tersebut dan untuk mencukupi kebutuhan sayuran rumah tangga di masyarakat sekitar. Latar belakang dari tema ini adalah ketertarikan kami terhadap lahan kosong dan mengembangkan beberapa hidroponik 
172 | Pendampingan Masyarakat Candi dalam Budidaya Tanaman Sawi ...

yang sudah ada di masyarakat.

Layaknya ibu rumah tangga pastinya menginginkan anggaran belanja masak dapat menghemat kondisi keuangan, sasaran sosialisasi kami adalah para ibu-ibu yang hampir setiap harinya mengkonsumsi sayuran. Mereka antusias mendengarkan materi sosialisasi yang kami sampaikan.

Properti kegiatan kami lumayan menguras tenaga yang mulai dari persiapan, pembuatan rangkaian tanaman hidroponik, sampai mempersiapkan bibit tanaman. Materi ini menjelaskan tata cara menanam di rockwool dengan air serta cara perawatannya, selain membacakan materi kami juga mempraktekkannya didepan warga sekitar. Sayuran merupakan salah satu bahan makanan yang banyak mengandung manfaat yang diperlukan bagi kesehatan tubuh manusia. Oleh karena itu, kami sebagai mahasiswa yang melaksanakan pengabdian masyarakat berusaha dengan semaksimal mungkin untuk menjalankan program Hidroponik sebagai salah satu upaya kami dalam memberdayakan masyarakat terutama dalam hal bercocok tanam di lahan sempit. Kami berharap program Hidroponik ini menjadi salah satu program yang dapat dilanjutkan oleh masyarakat di Desa Candi sehingga kebutuhan masyarakat akan sayur - sayuran dapat terpenuhi dengan maksimal. Selain itu semoga program ini bisa menjadi salah satu pilihan warga yang ingin membuka usaha di tempat tinggalnya.

Mengingat pentingnya sayuran bagi kesehatan manusia, kami sangat mengharapkan dukungan dari masyarakat terutama ibu-ibu terkait dengan keberlangsungan program Hidroponik yang nantinya dikembangkan oleh masyarakat. Lahan-lahan sempit yang dimiliki masyarakat sangat bisa dijadikan potensi, salah satunya melalui pertanian hidroponik. Semoga benih yang telah disemai dapat bermanfaat dan dapat dijaga dengan baik.

Berikut sosialisasi yang disampaikan kepada masyarakat:

\section{Alat dan bahan}

Alat dan bahan yang digunakan yaitu pipa, galvalum, selang, pompa atau filter air kolam, styrofoam rockwool, netpot, kain flanel, benih sawi, nutrisi tanaman/AB 
Mix, dan air. Pembuataan media hidroponik perlu dirangkai terlebih dahulu, bentuknya disesuaikan keinginan. Setelah media hidroponik siap digunakan, lalu letakkan netpot berukuran $5 \mathrm{~mm}$ yang sudah ada kain flanel ke dalam media hidroponik yang sudah dilubangi. Kemudian letakkan rockwool yang sudah ditanami benih sawi ke dalam netpot tersebut. Untuk saluran ainya melalui styrofoam yang berisi air dengan pompa atau filter air kolam yang disalurkan melalui selang berukuran $7 \mathrm{~mm}$.

Teknik penanaman hidroponik merupakan teknik bercocok tanam yang ramah lingkungan. Sayuran yang ditanam dengan hidroponik lebih sehat serta aman dikonsumsi. Sebagian orang mungkin masih sangat asing dengan tanaman hidroponik. Namun sebenarnya sudah banyak orang yang menggunakan metode penanaman tanaman yang satu ini.

\section{Tahapan Cara menanam hidroponik}

1. Penyemaian Benih Tanaman

Sebelum di tanam menggunakan media tanam, bibit disemaikan terlebih dahulu dengan tray atau wadah semai. Gunakan bibit yang tingkat pertumbuhannya mencapai $80 \%$. Setelah benih sudah tumbuh dan cukup umur (kurang lebih 1 mingguan), barulah dipindahkan ke media tanam.

2. Menyiapkan Media Tanam

Jenis media tanam yang bisa digunakan untuk tanaman hidroponik sangat banyak. Media tersebut bisa didapatkannya dengan cara membeli di toko pertanian. Kita disini memakai rockwool dan netpot. Lalu letakan media tanam yang telah dibuat pada wadah yang akan digunakan untuk menanam. Bisa menggunakan botol bekas, pipa paralon atau media lain yang tersedia di sekitar tempat tingga Anda.

3. Pemberian Nutrisi

Pemberian nutrisi sangatlah penting. Karena menanam tanpa menggunakan tanah, membuat cadangan makanan untuk tanaman sangat terbatas. Nutrisi yang diberikan biasanya berupa nutrisi cair, sehingga mudah diserap oleh tanaman. 
174 | Pendampingan Masyarakat Candi dalam Budidaya Tanaman Sawi ...

Cara pemberian nutrisi bisa dilakukan dengan cara di siram manual setiap pagi atau sore hari atau menambahkan pada tempat penampungan air (styrofoam, ember dll) .

4. Perawatan Tanaman

Cara merawat tanaman hidroponik adalah dengan melakukan penyiraman setiap pagi atau sore hari, serta memberikan nutrisi secara berkala.

\section{Pengamatan Lingkungan}

1. Intensitas cahaya

Pengukuran dilakukan untuk mengetahui berapa besar intensitas cahaya yang diterima oleh tanaman tiap minggu.

2. Suhu Udara

Suhu udara diukur pada siang hari. Posisi pengukuran dilakukan di sekitar media hidroponik

3. Air

Air yang digunakan harus bersih. Air diletakkan ke dalam styrofoam dan ditutup.

4. Konsumsi air

Menggunakan selang ukuran $7 \mathrm{~mm}$ untuk mengaliri ke dalam pipa pada masingmasing netpot.

\section{Hasil}

Kadar PH air= 6 sampai 6,5ml. Jika air melebihi dapat merusak tanaman atau perkembangan tidak maksimal. Untuk melarutkan nutrisi AB Mix agar tanaman dapat tumbuh kembang dengan sempurna :

Air 1liter, Nutrisi kepekatan 500 sd 800 ppm. Untuk mengukur nutrisi kami menggunakan TDS meter (Gambar 3.b)

Tuangkan larutan A dan B ke dalam air, masing-masing $5 \mathrm{ml}$.

Apabila masih kurang dari angkaa 800 ppm, maka perlu ditambahkan larutan A dan B sampai mencapai angka 800 ppm. 

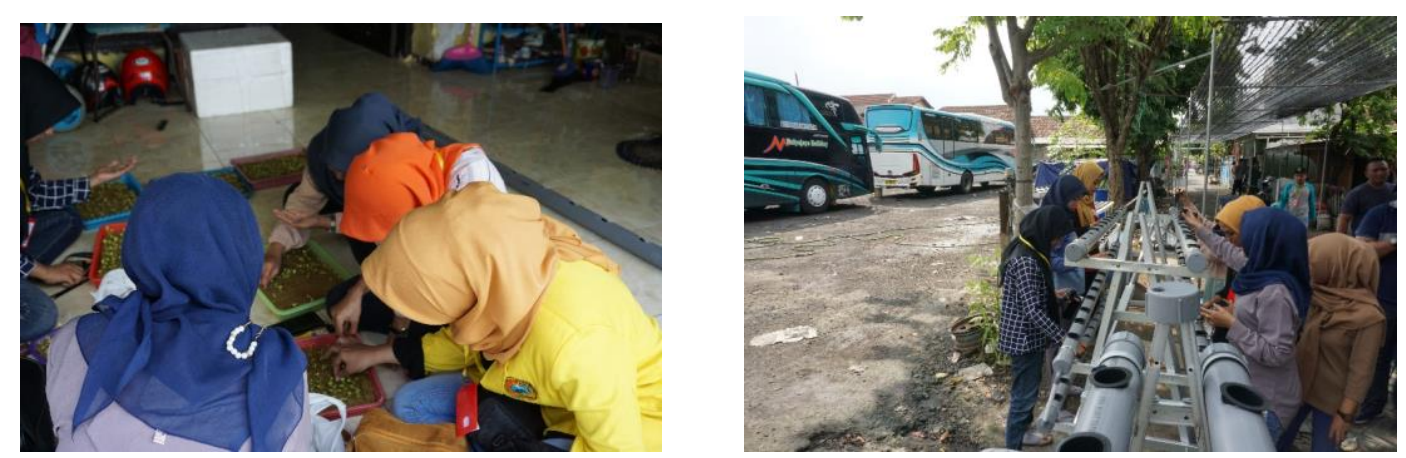

Gambar 2. Proses Pemindahan Bibit Ke Media Tanam Hidroponik

\section{Kesimpulan}

Pengabdian masyarakat ini merupakan salah satu model pengabdian kepada masyarakat yang dilakukan oleh tim pengabdian masyarakat Universitas Bhayangkara Surabaya. Pengabdian masyarakat ini perlu diarahkan dalam memecahkan masalah yang dihadapi masyarakat setempat. Oleh karena itu pemecahan masalah dalam masyarakat perlu diupayakan pendekatan sosialisasi tentang tanaman hidroponik agar masyarakat Candi Sidoarjo lebih bisa mengenal tanaman hidroponik dan bisa memanfaatkan lahan yang kosong. Selain untuk memenuhi kebutuhan sehari-hari diharapkan apabila warga sudah paham dan sanggup memberdayakan tanaman hidroponik, khususnya sawi ini dapat dijual kepada kosumen sehingga dapat menambah penghasilan keluarga.

\section{Ucapan Terma Kasih}

Ucapan terima kasih disampaikan kepada Kepala Desa Candi dan jajarannya, masyarakat Desa Candi serta peran serta dan kerja sama dari tim pelaksana kegiatan pengabdian masyarakat Universitas Bhayangkara Surabaya dari program studi Ilmu Hukum: Son Fitroni Hidayat 1611121055, Yohanes Nataliawan Saputra 1611121132, Kevyn Destawan Putra 1611121024, Bayu Rohman Hakim 1611121154, M. Samsul Bahri 1611121038, Hilda Eka Puspita 1611121022, dari program studi Manajemen: Ella Indirawati A 1712121011, Refita Alce 
176 | Pendampingan Masyarakat Candi dalam Budidaya Tanaman Sawi ...

1712121013, dari program studi Ekonomi Pembangunan: Lintang Sania 1712221008, Elok Yulinda Sari Wardani 1712221009, dan dari program studi Akuntansi: M. Arief Dwi Kurnia 1712321074, Rif'atul Aliyah 1712321067, Lia Anatasya 1712321021, Riska Yuliana 1712321006, Dariyanti 1812322003

\section{Daftar Pustaka}

Aksa, M., P, J., \& Subandriyanto. (2016). Rekayasa Media Tanam Pada Sistem Penanaman Hidroponik Untuk MENINGKATKAN PERTUMBUHAN TANAMAN SAYURAN. Jurnal Pendidikan Teknologi Pertanian, 2, 163168.

Harahap, Q. H. (2018). INTERAKSI SISTEM PERTANAMAN HIDROPONIK DENGAN PEMBERIAN NUTRISI AB MIX TERHADAP PERTUMBUHAN DAN PRODUKSI SAWI (Brassica juncea L). Jurnal AGROHITA: Jurnal Agroteknologi Fakultas Pertanian Universitas Muhammadiyah Tapanuli Selatan, 2(2), 61.

Masduki, A. (2018). HIDROPONIK SEBAGAI SARANA PEMANFAATAN LAHAN SEMPIT DI DUSUN RANDUBELANG, BANGUNHARJO, SEWON, BANTUL. Jurnal Pemberdayaan: Publikasi Hasil Pengabdian Kepada Masyarakat, 1(2), 185.

Rakhman, A., Lanya, B., Rosadi, R. A. B., \& Zen Kadir, M. (n.d.). PERTUMBUHAN TANAMAN SAWI MENGGUNAKAN SISTEM HIDROPONIK DAN AKUAPONIK THE GROWTH OF MUSTARD USING HYDROPONICS AND AQUAPONICS SYSTEMS. In Jurnal Teknik Pertanian Lampung (Vol. 4).

Roidah, I. S. (2014). Pemanfaatan Lahan Dengan Menggunakan Sistem Hidroponik. Jurnal Universitas Tulungagung BONOROWO Tahun, 1(2), 4350. 